\title{
The United States' Zero Tolerance Immigration Policy: An Analysis of Structural Violence
}

\author{
Kebijakan Imigrasi Zero Tolerance Amerika Serikat: \\ Analisis Kekerasan Struktural
}

\author{
Karina Utami Dewi \& Desti Putri Cahyani \\ Universitas Islam Indonesia
}

\begin{abstract}
ABSTRAK
Kebijakan imigrasi Zero Tolerance merupakan salah satu bentuk kebijakan yang diformulasikan oleh pemerintahan Donald Trump dengan tujuan untuk mengurangi jumlah imigran tanpa dokumen yang memasuki wilayah Amerika Serikat. Kebijakan imigrasi ini menjadi isu yang mendapat sorotan dari dunia internasional karena sarat dengan pelanggaran hak-hak asasi manusia, dan memosisikan imigran tanpa dokumen serta anak-anak dalam keadaan yang rentan. Tulisan ini mengelaborasi bahwa kebijakan ini mengindikasikan kekerasan struktural pada penerapannya, dengan menggunakan konsep Kekerasan Struktural yang ditulis oleh Johan Galtung, dan mencoba membuktikan terjadinya kekerasan struktural serta alasan mengapa kebijakan ini dilakukan oleh Amerika Serikat. Terdapat tiga argumen utama pada tulisan ini; pertama, kekerasan struktural terbukti telah dilakukan oleh Amerika Serikat dapat dilihat melalui subjek, objek, serta tindakan dalam konsep Kekerasan Struktural. Kedua, terdapat faktor pendorong yang sifatnya sengaja dan tidak sengaja dalam melakukan kebijakan yang mengakibatkan kekerasan struktural. Yang ketiga, Amerika Serikat menjalankan kebijakan ini dengan menggunakan pendekatan yang menekankan pada reward dan punishment.
\end{abstract}

Kata-kata kunci: imigrasi, kekerasan struktural, Amerika Serikat

Zero Tolerance Immigration Policy is one form of policy formulated by the Donald Trump administration to reduce undocumented immigrants entering the United States. This immigration policy has become an issue of international attention because it is full of human rights violations, and places the undocumented immigrants and children in an unsafe condition. This paper describes that the policy mentioned above indicates structural violence in its implementation, employs the concept of Structural Violence written by Johan Galtung, and tries to prove the occurrence of structural violence and the reasons why this policy was carried out by the United States. There are three main arguments in this paper; first, there is indeed structural violence that has been committed by the United States as observed in the object, subject, and actions in the concept of Structural Violence. Second, there are intended and unintended motivations in implementing this policy, which encouraged structural violence. Third, The United States carries out this policy by using an approach that emphasizes reward and punishment.

Keywords: immigration, structural violence, United States 
Pada 6 April 2018, Presiden Trump merilis kebijakan imigrasi yang bertujuan untuk melakukan penahanan bagi imigran yang memasuki wilayah Amerika (Department of Justice 2018). Penahanan bagi imigran tanpa dokumen dan pencari suaka tersebut berdampak pada kondisi pemisahan keluarga imigran. Pada praktiknya, imigran yang membawa anak akan dipenjarakan tanpa terkecuali dan anak dari imigran tersebut akan dikumpulkan dalam suatu penampungan terpisah. Kebijakan pemisahan keluarga di perbatasan ini dikenal sebagai kebijakan imigrasi Zero Tolerance. Kebijakan ini dilaksanakan di perbatasan Amerika Serikat dan Meksiko secara tidak resmi sejak akhir 2017 yang tujuannya adalah untuk memberikan efek jera bagi imigran tanpa dokumen serta untuk mengurangi beban dalam memproses pencari suaka. Penerapan kebijakan imigrasi Zero Tolerance ini dilakukan dengan menahan imigran di tahanan federal Amerika Serikat dan memisahkan anak-anak yang orang tuanya ditahan untuk ditempatkan di bawah pengawasan Department of Health and Human Services (Narea 2019). Praktik kebijakan imigrasi Zero Tolerance ini menuai cukup banyak kontroversi dari dunia internasional karena dianggap tidak sejalan dengan nilai-nilai HAM yang seharusnya dijunjung oleh negara demokratis seperti Amerika (Davis 2018; Amnesty International 2018). Dampak dari kebijakan ini salah satunya tercatat kurang lebih sebanyak 3.000 anak telah terpisah dari orangtuanya dan 100 di antaranya berusia kurang dari lima tahun (Human Rights Watch 2018). Pada Juni 2018, karena desakan domestik dan internasional, kebijakan ini secara resmi diberhentikan melalui executive order Presiden Trump (Thompson 2018). Meskipun demikian, secara tidak resmi kebijakan ini masih terus berlangsung setidaknya hingga Oktober 2019 (Narea 2019).

Tulisan ini membahas mengenai penerapan kebijakan imigrasi Zero Tolerance dari perspektif Kekerasan Struktural yang ditulis oleh Johan Galtung. Kekerasan struktural sendiri didefinisikan sebagai kekerasan yang dilakukan oleh struktur sosial ataupun institusi, seperti pemerintah, yang menghalangi manusia dalam memenuhi kebutuhan dasarnya, dan bahkan dapat menimbulkan dampak fisik serta psikologis. Kekerasaan struktural secara umum terjadi di bawah distribusi kekuasaan yang kemudian memiliki hubungan dengan ketidaksetaraan yang dirasakan sekelompok orang di bawah pemegang kekuasaan tersebut (Galtung 1969, 168). Pendekatan ini menekankan bahwa pada kekerasan terdapat subjek, objek, dan tindakan sehingga sesuai untuk digunakan dalam memberikan analisis kritis terhadap kebijakan Amerika Serikat tersebut secara komprehensif. Selain itu, kebijakan Amerika Serikat ini juga menekankan adanya ketimpangan kekuasaan yang kemudian disalahgunakan untuk menindas orang lain atau kelompok tertentu. Hal ini sesuai dengan yang diungkapkan oleh Galtung mengenai ketidaksetaraan distribusi kekuasaan. Tulisan ini membuktikan bahwa kebijakan yang dilakukan oleh Amerika Serikat tersebut merupakan kekerasan struktural dan menjawab alasan Amerika Serikat menerapkan kebijakan imigrasi Zero Tolerance yang terindikasi merupakan bentuk kekerasan struktural. Berdasarkan proposisi Galtung tersebut, penulis berargumen bahwa terdapat kekerasan struktural yang dialami oleh imigran akibat kebijakan anti imigrasi ini. Kekerasan struktural tersebut didorong dengan motivasi tertentu yang akan dijelaskan dengan lebih detail dalam tulisan ini.

\section{Kebijakan Anti-Imigrasi oleh Amerika Serikat}

Kebijakan imigrasi Zero Tolerance secara langsung berada di bawah United States Department of Homeland Security (DHS), dan telah mulai diimplementasikan secara tidak resmi pada Oktober 2017, sebelum akhirnya resmi diterapkan pada April 2018 (Hildreth 2019). Presiden Trump, Jeff Sessions, Stephen Miller, dan John Kelly merupakan aktor penting yang berada dibalik munculnya kebijakan ini, sementara Senator Partai Republik merupakan salah satu yang membuat kebijakan 
ini terimplementasi melalui proses voting dalam kongres (Hildreth 2019). Teknik pemisahan imigran ini merupakan upaya yang diperlukan pemerintah untuk dapat meningkatkan keamanan perbatasan, hal tersebut yang kemudian melatarbelakangi John Kelly sebagai kepala staff pemerintahan Trump saat itu untuk mendukung proses implementasinya (Bump 2018). Terdapat beberapa instrumen negara yang berperan penting dalam proses implementasi kebijakan imigrasi Zero Tolerance yaitu, United States Department of Homeland Security (DHS), Custom and Border Protection (CBP), Office of Refugee Resettlement (ORR), dan Immigration and Customs Enforcement (ICE) (U.S. Customs and Border Protection 2018).

ORR misalnya, memiliki peran dalam mengupayakan dan memfasilitasi anak-anak imigran yang mengalami permasalahan seperti, tidak ada tempat untuk tidur, merasa tidak nyaman karena seseorang, dijauhkan dari makanan, penampungan, pendidikan, atau obat, merasa tidak aman dan tidak diinginkan, mendapat permasalahan keluarga, dan kesulitan dalam mendapatkan pertolongan (Office of Refugee Resettlement 2015). Sementara ICE akan memberikan fasilitas bagi orang tua yang ditahan dengan memfasilitasi komunikasi keluarga secara rutin dan menambah staf yang memiliki keahlian untuk memberikan layanan kesehatan mental (Department of Homeland Security 2018). Namun pada praktiknya, DHS dianggap tidak memiliki kapasitas untuk menyediakan fasilitas-fasilitas tersebut, termasuk dalam hal yang mendasar seperti informasi keluarga. Proses komunikasi merupakan sebuah permasalahan yang tidak dapat teratasi dalam kebijakan ini (Brane 2019).

Selama jangka waktu kebijakan imigrasi Zero Tolerance diterapkan secara resmi maupun tidak, terdapat pihak-pihak yang telah terdampak, yaitu para objek kebijakan tersebut yang kemudian menjadi korban dari kekerasan struktural. Dalam kasus ini, objek atau korban tersebut dapat diklasifikasikan menjadi dua yaitu, para imigran dan anak-anak imigran. Kebijakan pemisahan keluarga tersebut menyebabkan imigran kehilangan bagian dari keluarganya. Kecemasan akan kondisi anak-anak yang berada di penampungan juga dirasakan oleh keluarga korban yang sedang menunggu masa hukuman peradilan maupun keluarga dari negara asalnya. Diperkirakan terdapat sebanyak 29 kasus keluarga yang secara sengaja tidak dapat dilakukan proses reunifikasi oleh karena DHS menilai ketidaklayakan orang tua imigran tersebut seperti adanya dugaan kriminal (Wiley 2018). Sementara, berhasilnya proses reunifikasi pada beberapa kasus juga mengalami masalah seperti terdapat kekeliruan pengembalian anak kepada orang tua (Rizzo 2018).

Terdapat pula berbagai dampak yang dialami oleh objek dari kebijakan imigrasi Amerika Serikat ini, yang dapat diklasifikasi dalam dua bentuk yaitu dampak fisik dan psikologis. Pertama, dampak fisik dialami oleh anak-anak imigran yang ditempatkan pada penampungan dengan kondisi yang dinilai kurang dapat memfasilitasi proses tumbuh kembang anak dengan sanitasi dan kondisi penampungan yang tidak higienis yang menyebabkan mereka mengalami berbagai penyakit, bahkan hingga meninggal dunia. Pada 2019, tercatat lima orang anak berusia 2-16 tahun meninggal dunia karena menderita penyakit seperti pneumonia, demam tinggi, infeksi bagian otak, infeksi bakteri, dan influenza (Gumbel 2018; Redlener 2019). Anak-anak ini juga mengalami tindak kekerasan fisik yang dilakukan oleh staff pemerintah yang berjaga sehingga mengakibatkan memar di pergelangan tangan, rusuk, dan bahu (Watson 2018). Dengan dalih sebagai upaya mencegah perilaku agresif yang muncul, anak-anak diborgol dan diikat tangan dan kakinya, serta diberikan pil penenang yang berdampak negatif pada kondisi fisik mereka (CNN Investigates 2018). Tidak hanya itu, dalam kurun waktu Maret-Juli 2018, terdapat 859 pengaduan ke pengadilan terkait kasus pelecehan seksual yang dilakukan oleh petugas penahanan (Haag 2019). Dampak fisik juga terjadi pada imigran dewasa yang ditahan karena mereka mengalami kelaparan dan sakit akibat kondisi penahanan yang tidak layak (Romero et al. 2019). 
Di samping dampak fisik, dampak psikologis juga terjadi pada keluarga imigran akibat penerapan kebijakan imigrasi Zero Tolerance. Bermula dari proses pemisahan dari keluarga, kemudian penempatan anak-anak imigran ke dalam penampungan secara bersamaan. Keadaan tidak saling mengenal dan perbedaan identitas seperti bahasa membuat anak-anak tersebut harus menyesuaikan satu dengan yang lain. Anakanak imigran juga mengalami dinamika emosi dan trauma psikologis karena harus dipisahkan dari keluarganya (Watson 2018; International Rescue Committee 2018). Imigran dewasa juga merasakan dampak psikologis karena mereka mengalami ketakutan ketika berada dalam tahanan (Romero et al. 2019). Pada beberapa keluarga yang berhasil reunifikasi, tercatat bahwa terdapat anak yang secara terus menerus menangis karena tidak mengenali keluarganya. Keluarga juga merasakan dampak psikologis yang signifikan, terutama anak-anak yang merasakan gangguan kecemasan karena takut terpisah dengan keluarganya lagi (Lussenhop 2018).

\section{Kekerasan Struktural dalam Kebijakan Imigrasi Zero Tolerance}

Kebijakan imigrasi Zero Tolerance dapat dilihat dari kacamata Kekerasan Struktural, dengan mengamati subjek, objek, dan tindakannya (Galtung 1969, 169). Pertama, terkait subjek. Galtung menjelaskan bahwa terdapat berbagai jenis aktor yang dapat diklasifikasi sebagai subjek dalam tindakan kekerasan struktural. Subjek dapat dikatakan melakukan kekerasan struktural apabila melakukan tindak kekerasan di dalam sebuah struktur, dalam hal ini subjek memiliki posisi yang lebih tinggi dari objek secara kedudukan struktur. Subjek yang disebutkan dalam konsep Kekerasan Struktural dapat berupa individu atau secara langsung, dan tidak ada aktor atau secara struktur (Galtung 1969, 170).

Aktor yang menjadi subjek dalam kebijakan ini adalah pemerintah Amerika Serikat. Posisi hierarki subjek yang disebutkan dalam konsep Kekerasan Struktural, juga terlihat dari posisi Amerika Serikat sebagai suatu negara yang memiliki otoritas penuh dalam pembuatan kebijakan (Galtung 1969, 170). Kelompok otoritas ini yang kemudian dapat dilegitimasi sebagai subjek dalam konsep Kekerasan Struktural yang kemudian akan menghasilkan kerangka kerja. Negara merupakan suatu entitas yang memiliki otoritas penuh, sehingga secara tatanan struktur berada pada bagian atas. Kebijakan ini mampu membuat objek yang posisinya lebih rendah untuk patuh pada sistem struktur ini (Galtung 1969, 178). Kebijakan berupa dokumen kebijakan imigrasi Zero Tolerance merupakan sebuah kerangka kerja yang dalam konsep Kekerasan Struktural memiliki kekuatan untuk mengatur, dengan pemerintah Amerika Serikat sebagai subjeknya.

Kedua, terkait objek. Galtung menelaah berkenaan dengan karakter objek yang dapat dijustifikasi sebagai korban dari kekerasan struktural yang terjadi. Kekerasan tidak dapat terjadi apabila tidak ada objek yang merasa terluka secara fisik atau psikologis. Objek tidak harus mengalami dampak kekerasan secara langsung untuk dapat dikategorikan terluka, rasa tidak aman yang muncul akibat ancaman juga mengindikasikan adanya sebuah kekerasan (Galtung 1969, 170). Secara spesifik, Galtung menyebutkan bahwa yang dapat menjadi objek kekerasan struktural adalah individu atau kelompok yang merupakan masyarakat dari sebuah sistem atau struktur (Galtung 1969, 179). Seperti yang telah dijelaskan di atas, dalam kasus kebijakan imigrasi Zero Tolerance ini, klasifikasi objek adalah para imigran sendiri yang mencoba memasuki perbatasan Amerika dari Meksiko, dan anak-anak mereka yang dipisahkan saat proses penahanan.

Ketiga, terkait aksi atau tindakan. Galtung menjelaskan bahwa sebuah kekerasan 
dapat terjadi apabila ditemukan perbedaan atau ketidakseimbangan antara realisasi aktual dan potensi oleh subjek kekerasan. Realisasi aktual merupakan sebuah kemampuan subjek dalam mengatur tindakannya untuk mengatasi sebuah fenomena, sedangkan potensial dalam konteks kekerasan adalah sebuah kemungkinan akan hadirnya kekerasan yang dirasakan. Kekerasan akan muncul apabila tingkat potensi yang tinggi tidak diimbangi dengan tingginya aktualisasi. Selanjutnya terdapat dua tingkat kekerasan yaitu latent dan manifest. Latent merupakan suatu situasi yang tidak menunjukkan adanya kekerasan, namun sangat memungkinkan akan hadirnya kekerasan. Sementara manifest merupakan suatu situasi di mana kekerasan yang ada dapat terobservasi sehingga selama kekerasan tersebut berlangsung akan terlihat secara nyata dan disadari sebagai sebuah tindakan kekerasan (Galtung 1969, 172). Dalam kasus kebijakan imigrasi Zero Tolerance, potensi kekerasan terjadi karena subjek, yang dalam hal ini Pemerintah Amerika Serikat, tidak menjalankan realisasi aktualnya sebagaimana seharusnya. Fasilitas bagi imigran maupun anak-anaknya yang tidak dipenuhi oleh badan-badan pemerintahan seperti ORR atau ICE di bawah DHS, memberikan dampak-dampak yang signifikan pada objek kebijakan yaitu para imigran dan anak-anaknya (Brane 2019; Jacobs 2019). Hal ini semakin membuktikan bahwa terdapat kekerasan yang nyata atau dapat diobservasi sehingga mengindikasikan kebijakan ini menghasilkan kekerasan dari struktur yang bersifat manifest.

Sementara itu, dampak yang ditimbulkan setelah kebijakan imigrasi Zero Tolerance diterapkan dapat terbagi menjadi dua, yaitu dampak fisik dan dampak psikologis terhadap objek yang menjadi korban. Galtung menjelaskan bahwa fisik yang terluka karena terjadinya kekerasan akan membatasi ruang gerak manusia. Hal ini menyebabkan kondisi seseorang menjadi kesulitan atau bahkan tidak mendapatkan distribusi akses-akses kebutuhan manusia karena gerak tubuh yang terbatas (Galtung 1969, 169). Dampak kekerasan fisik dapat ditimbulkan dengan alat-alat maupun tanpa alat seperti dengan menggunakan bagian tubuh (Galtung 1969, 174). Kedua hal ini terjadi pada imigran yang mengalami sakit dan kelaparan, serta pada anakanak imigran yang mengalami sakit, luka-luka, menerima pelecehan seksual, bahkan hingga meninggal dunia.

Terkait dampak psikologis, Galtung menyebutkan bahwa kekerasan psikologis merupakan bentuk dari kekerasan jiwa yang dapat berpengaruh dalam kehidupan individu, meskipun lebih sulit untuk diidentifikasi. Jika kekerasan fisik secara jelas dapat membatasi mobilitas individu, kekerasan psikologis ini menyerang jiwa setiap individu yang kemudian akan berpengaruh pada rangkaian perilaku. Bentuk-bentuk yang mengancam kesehatan psikologis kemudian akan membahayakan dan melukai mental individu (Galtung 1969, 169). Hal tersebut juga terjadi pada objek kebijakan Zero Tolerance yang mengalami kekerasan struktural, yaitu pada imigran yang merasakan ketakutan dan kecemasan serta anak-anak imigran yang terpisah dari keluarga dan mengalami gangguan kecemasan, dinamika emosi, dan trauma sebagai dampak dari kebijakan imigrasi Zero Tolerance.

Dari penjelasan di atas, dapat dilihat bahwa hal-hal yang dilakukan pemerintah Amerika Serikat melalui kebijakan imigrasi Zero Tolerance ini merupakan bentuk kekerasan struktural, karena sesuai dengan poin-poin yang dikemukakan oleh Galtung terkait subjek, objek, serta tindakan yang dilakukan yang kemudian menimbulkan berbagai dampak. Selanjutnya, dalam pendekatan Kekerasan Struktural, Galtung juga mendiskusikan mengenai motivasi atau dorongan dalam mengambil suatu tindakan serta pendekatan yang ada di dalamnya. Penjelasan Galtung tersebut akan digunakan untuk menjawab pertanyaan mengapa Amerika Serikat menerapkan kebijakan yang menyebabkan kekerasan struktural ini. 


\section{Motivasi dan Pendekatan yang Dilakukan Amerika Serikat}

Penerapan kebijakan imigrasi Zero Tolerence merupakan sebuah bentuk upaya pemerintahan Donald Trump untuk mengurangi jumlah imigran di dalam Amerika Serikat. Di bawah Department of Justice (DOJ), Amerika menyatakan komitmennya dalam penuntutan untuk menangkap seluruh imigran dewasa yang memasuki batas teritori Amerika Serikat, tanpa pengecualian mengenai kriteria imigran yang akan mendapatkan pengadilan sehingga berlaku bagi imigran tanpa dokumen maupun pencari suaka (Congressional Research Service 2019, 1). Amerika berfokus untuk mencegah bertambahnya imigran karena hal tersebut dapat mengancam berbagai sektor domestik Amerika Serikat, antara lain ekonomi dan keamanan. Kebijakan ini dimaksudkan untuk mengurangi jumlah imigran tanpa dokumen untuk menjaga kemananan wilayah Amerika Serikat dan membuat sebuah sistem kebijakan imigrasi untuk melindungi kesejahteraan ekonomi masyarakat dalam negeri (The White House 2019).

Terjadinya pemisahan keluarga merupakan konsekuensi dari kebijakan imigrasi yang menahan imigran tanpa terkecuali, termasuk imigran yang datang bersama anaknya (Jordan 2018). Meskipun demikian, berjalannya kebijakan ini termotivasi dari kebijakan imigrasi yang telah ada sebelumnya. Pada masa pemerintahan Presiden Bush dan Obama, terdapat kebijakan imigrasi yang dinilai serupa dengan kebijakan imigrasi pada masa Presiden Trump. Hal tersebut yang membuat pemerintahan Trump memandang bahwa kebijakan imigrasi Zero Tolerance bukan merupakan hal baru yang diterapkan di Amerika Serikat (U.S. House of Representative 2019). Kebijakan anti-imigrasi ini telah digaungkan oleh Donald Trump bahkan sejak kampanyenya, sebelum masa pemilihan presiden. Trump mengatakan bahwa banyak imigran yang datang membawa obat-obatan terlarang, membawa sejumlah dampak kriminal, dan Trump tidak akan membiarkan banyaknya jumlah imigran membuat angka kemiskinan di Amerika meningkat (Lind 2019). Meskipun beberapa pakar ekonomi justru sepakat bahwa hadirnya imigran sebetulnya tidak membuat orang-orang Amerika kehilangan pekerjaan, hal ini karena pekerjaan yang diambil oleh imigran merupakan pekerjaan yang tidak diminati oleh orang-orang Amerika (Frazee 2018).

Selain menjelaskan subjek, objek, serta tindakan dalam kekerasan struktural, Galtung juga menjelaskan tentang dua hal, yaitu tentang motivasi atau dorongan, dan pendekatan yang dilakukan suatu aktor dalam mengambil tindakan. Motivasi atau dorongan dijelaskan Galtung dalam dua bentuk, yaitu intended dan uninented (Galtung 1969, 171). Intended terjadi ketika terdapat niat yang jelas dari subjek yang secara sengaja melakukan kekerasan. Sementara unintended adalah kekerasan yang terjadi secara tidak disengaja atau tidak disertai dengan niat untuk melukai. Sementara pendekatan dalam mengambil suatu tindakan atau dalam hal ini, kebijakan, juga dijelaskan dalam dua bentuk, yaitu pendekatan positif dan negatif (Galtung 1969, 172). Pendekatan positif adalah ketika terdapat subjek yang melakukan tindakan dengan harapan akan mendapat sebuah reward atas apa yang dilakukan. Pendekatan negatif adalah upaya yang dilakukan oleh subjek untuk merespon terhadap suatu hal yang dianggap merugikan sehingga perlu diberikan sebuah punishment. Pendekatan negatif diperlukan untuk membatasi gerak dan potensi objek sehingga pendekatan ini dilakukan untuk mencegah tindakan objek (Galtung 1969, 170).

Pertama, motivasi atau dorongan pemerintah Amerika Serikat dalam mengambil kebijakan imigrasi Zero Tolerance dapat dilihat dari dua sisi. Di satu sisi, apabila hanya mengacu pada pernyataan pemerintah Amerika Serikat terkait alasan keamanan dan ekonomi, maka kekerasan struktural yang ditimbulkan dari kebijakan ini dapat digolongkan unintended atau tidak disengaja. Karena tidak diniatkan untuk sengaja menyakiti atau melukai kelompok tertentu, melainkan merupakan konsekuensi 
dari kebijakan imigrasi yang menahan imigran tanpa terkecuali. Namun di sisi lain, berbagai dugaan muncul bahwa kebijakan ini merupakan perwujudan dari supremasi kulit putih dengan mendiskriminasi kaum Hispanik yang banyak menjadikan Amerika sebagai negara tujuan untuk berimigrasi dan mencari suaka (Srikantiah \& Sinnar 2019; Radford 2019). Dalam konteks ini, maka kekerasan struktural yang terjadi dapat digolongkan sebagai intended atau disengaja karena subjek telah memiliki niat atau dorongan untuk melakukan kekerasan maka hal tersebut diperhitungkan sebagai sebuah fenomena kekerasan (Galtung 1969, 171). Meskipun tentunya hal ini dapat diperdebatkan karena tidak ada satu pun dokumen ataupun pernyataan pemerintah Amerika Serikat yang secara resmi mengonfirmasi bahwa kebijakan ini adalah perwujudan supremasi kulit putih dan diskriminasi rasial terhadap kaum tertentu.

Kedua, dalam melihat pendekatan yang dilakukan Amerika Serikat saat mengimplementasikan kebijakan imigrasi Zero Tolerance, kedua pendekatan yang dijelaskan oleh Galtung, yaitu positif dan negatif, muncul pada penerapan kebijakan tersebut. Pendekatan posistif terjadi ketika Trump, dengan berbagai asumsi mengenai imigran yang banyak merugikan Amerika, mengambil kebijakan ini untuk melindungi kepentingan Amerika dan menciptakan kondisi negara sesuai dengan idealismenya. Artinya, kebijakan ini diambil karena terdapat hasil positif apabila tindakan ini dilakukan. Seperti konsepsi reward, ketika Trump berhasil menciptakan kondisi yang dapat memajukan Amerika dengan memberikan banyak lapangan pekerjaan bagi penduduk Amerika, menciptakan keamanan perbatasan, menurunkan tingkat kriminalitas, maka akan tercipta Amerika yang semakin baik sehingga membuat kredibilitas Donald Trump sebagai presiden diakui secara domestik dan internasional. Pengakuan kredibilitas merupakan salah satu bentuk penghargaan dan membuat masyarakat akan membenarkan atas apa yang dilakukan, dan bahkan dapat menjadi isu penting untuk membantu Trump memenangkan pemilu di 2020 (Alter 2019; Whitesides 2020). Hal ini sesuai dengan apa yang diungkapkan oleh Galtung bahwa pendekatan positif melakukan tindakan yang dilakukan atas dasar penghargaan atau reward untuk dirinya (Galtung 1969, 172).

Selain itu, kebijakan ini juga diimplementasi berdasarkan pengaruh negatif. Hal ini terlihat dari pernyataan Trump tentang dampak kriminal dan angka kemiskinan akibat imigran yang kemudian mendorong diciptakannya kebijakan anti-imigran. Konstruksi imigran yang meningkatkan angka kriminalitas, mengambil sejumlah lapangan pekerjaan sehingga mengancam keamanan dan ekonomi, menjadi alasan pemerintah Amerika Serikat untuk membuat kebijakan yang membatasi potensi tersebut. Hal ini selaras dengan penjelasan Galtung mengenai pendekatan negatif, bahwa pendekatan ini berpengaruh dalam menghentikan potensi sesuatu yang sifatnya mengancam atau membahayakan. Pendekatan negatif berarti membatasi sesuatu yang berpotensi ancaman atau merupakan bentuk dari sebuah hukuman bagi objek karena telah melakukan kesalahan (Galtung 1969, 172). Dalam kasus kebijakan imigrasi Zero Tolerance, adanya ancaman ini kemudian mendorong kebijakan yang sifatnya memberikan hukuman atau punishment diberikan kepada imigran tanpa dokumen dan pencari suaka yang melintasi perbatasan Amerika Serikat-Meksiko.

Berdasarkan penjelasan di atas, dapat dilihat alasan dari pemberlakuan kebijakan ini terdiri dari dua bagian. Bagian pertama, dari motivasi atau dorongan yang terbagi menjadi intended, yaitu Amerika di bawah Trump diduga dengan sengaja mengambil kebijakan ini karena adanya sentimen rasialisme dan supremasi kulit putih yang membuat imigran dari Amerika Latin mengalami diskriminasi. Serta dorongan yang sifatnya unintended, karena upaya untuk menciptakan keamanan dan kesejahteraan ekonomi menimbulkan konsekuensi yang membuat imigran dan pencari suaka menjadi korban kekerasan. Bagian kedua, dilihat dari pendekatan yang sifatnya positif, yaitu kekerasan struktural terjadi karena alasan yang positif dengan merujuk 
pada reward. Terdapat keinginan untuk meningkatan keamanan serta kesejahteraan ekonomi masyarakat Amerika, yang juga dapat berdampak pada kredibilitas Trump dan menaikkan posisinya menjelang pemilihan presiden pada tahun 2020. Serta pendekatan negatif yang memberikan gambaran yang buruk untuk menciptakan sentimen anti-imigran dan pemberian hukuman atau punishment bagi para imigran yang melanggar kebijakan ini.

\section{Simpulan}

Tulisan ini berfokus pada argumen bahwa Amerika Serikat dalam menerapkan kebijakan imigrasi Zero Tolerance telah melakukan kekerasan struktural. Dengan menggunakan konsep tersebut, dijelaskan pula alasan yang mendorong Amerika Serikat melakukan kebijakan yang berdampak pada kekerasan struktural tersebut. Terdapat tiga bagian utama dalam menjelaskan argumentasi ini. Bagian yang pertama adalah bahwa kebijakan imigrasi ini terbukti menimbulkan dampak kekerasan struktural, yang kedua adalah penjelasan yang mendorong pemerintahan Donald Trump dalam melaksanakan kebijakan ini, dan yang ketiga adalah adanya faktor pendekatan yang menekankan pada reward dan punishment dalam menerapkan kebijakan imigrasi Zero Tolerance ini.

Pada bagian pertama, kebijakan ini terbukti memiliki muatan kekerasan struktural dengan terpenuhinya poin-poin yang dijelaskan oleh Galtung, yaitu terdapat subjek, objek, serta tindakan. Subjek dalam konteks ini adalah Pemerintahan Amerika Serikat dan badan-badan di bawahnya yang memiliki otoritas dan secara hirarkis lebih tinggi sehingga memiliki wewenang dalam membuat sebuah kerangka kerja untuk mengatur objek kebijakan. Dalam hal ini, objek kekerasan struktural adalah imigranimigran tanpa dokumen serta anak-anaknya yang menjadi korban dari kebijakan ini. Sementara tindakan terbukti dari adanya kekerasan yang sifatnya ter-manifest, sesuai dengan yang disampaikan oleh Galtung, kekerasan ini sudah terlihat dan terobservasi bahkan sejak belum diterapkan secara resmi. Hal ini dibuktikan dengan banyaknya dampak fisik dan psikologis yang dialami oleh objek kekerasan struktural ini, seperti kelaparan, sakit, pelecehan seksual, trauma, kecemasan, hingga kematian.

Pada bagian kedua, terkait penjelasan yang mendorong pemerintahan Donald Trump dalam melaksanakan kebijakan ini. Galtung menjelaskan bahwa terdapat dua bentuk dorongan yang menyebabkan tindakan kekerasan seksual, yaitu dorongan yang disengaja (intended), dan dorongan yang tidak disengaja (unintended). Motivasi atau dorongan yang intended terjadi ketika Amerika di bawah Trump diduga dengan sengaja mengambil kebijakan ini karena adanya sentimen rasialisme dan supremasi kulit putih yang membuat imigran dari Amerika Latin menjadi terdiskriminasi. Serta dorongan yang sifatnya unintended, yaitu ketika upaya untuk menciptakan keamanan dan kesejahteraan ekonomi menimbulkan konsekuensi yang membuat imigran dan pencari suaka menjadi korban kekerasan.

Terakhir, pada bagian ketiga, terkait faktor pendekatan positif yang menekankan pada reward dan pendekatan negatif yang menekankan pada punishment dalam penerapan kebijakan imigrasi Zero Tolerance. Dilihat dari pendekatan yang sifatnya positif, kekerasan struktural terjadi karena alasan positif yang merujuk pada reward. Terdapat keinginan untuk meningkatkan keamanan dan kesejahteraan ekonomi masyarakat Amerika, serta menciptakan kondisi domestik yang lebih baik. Hal ini dapat menjadi reward bagi Donald Trump berupa kredibilitasnya sebagai presiden serta menjadi salah satu isu kunci baginya menjelang pemilihan presiden pada tahun 2020. Sementara pendekatan negatif memberikan gambaran buruk terhadap imigran 
untuk menciptakan sentimen anti-imigran dan pemberian hukuman atau punishment bagi para imigran yang melanggar kebijakan ini.

Berdasarkan penjelasan di atas, kebijakan imigrasi Zero Tolerance terbukti merupakan kebijakan yang menyebabkan terjadinya kekerasan struktural. Dalam penjelasan Galtung mengenai kekerasan struktural, terdapat enam dimensi yang menjelaskan terjadinya kekerasan struktural, yaitu meliputi objek, subjek, potensi dan aktualisasi kekerasan, dampak fisik dan psikologis, motivasi atau pendorong, serta pendekatan. Dalam penerapan kebijakan imigrasi Zero Tolerance, keenam dimensi muncul dan dapat dijelaskan sebagai pembuktian bahwa terjadi kekerasan struktural dalam implementasi kebijakan ini. Pada tahap lebih lanjut, kebijakan ini memiliki dampak kekerasan bahkan ketika kebijakan ini diakhiri. Kebijakan imigrasi ini menjadi isu yang mendapat sorotan dari dunia internasional karena sarat dengan pelanggaran hak-hak asasi manusia, dan memosisikan imigran tanpa dokumen serta anak-anak dalam keadaan yang rentan.

\section{Referensi}

\section{Buku dan Bab dalam Buku}

Raco, J., 2010. Metode Penelitian Kualitatif Jenis, Dimensi, dan Keunggulannya. Jakarta: Grasindo.

Ritzer, G., dan P. Dean, 2015. Globalization: A Basic Text Second Edition. Chichester: John Wiley \& Sons, Ltd.

\section{Jurnal dan Jurnal Daring}

Galtung, J., 1969. "Violence, peace, and peace research", Journal of Peace Research, 6(3): 167-191.

Galtung, J., 1990. “Cultural Violence”, Journal of Peace Research, 27(3): 291-305.

Sassen, S., 1989. “America's Immigration 'Problem”, World Policy Journal, 6(4): 811832.

Srikantiah, J., dan S. Sinnar, 2019. "White Nationalism as Immigration Policy", Standford Law Review Online, 71:197.

Wood, L.C., 2018. "Impact of punitive immigration policies, parent-child separation and child detention on the mental health and development of children". BMJ Paediatrics Open, 2(1).

\section{Artikel Daring}

Alter, C., 2019. "President Trump Wants to Highlight the Border. Who Does That Benefit?”, Time, 11 April, [daring]. dalam https://time.com/5566887/presidenttrump-wants-to-make-immigration-key-in-2020-who-does-that-help/ [diakses pada 15 Mei 2020].

Amadeo, K., 2018. "Immigration's Effect on the Economy and You”, The Balance, 20 April, [daring]. dalam https://www.thebalance.com/how-immigration-impacts-theeconomy-4125413 [diakses pada 15 Juni 2019].

Amnesty International, 2018. “USA: 'You don't have any rights here”' [daring]. dalam 
https://www.amnesty.org/en/latest/research/2018/10/usa-treatment-of-asylumseekers-southern-border/ [diakses pada 15 Mei 2020].

Andone, D., 2018. "Coast-to-coast protests denounce Trump immigration policies", CNN, 30 Juni, [daring]. dalam https://edition.cnn.com/2018/06/30/us/june-30immigration-protests/index.html [diakses pada 1 Juli 2019].

Aoláin, F. N., 2018. "Global Responses to President Trump's Family Separation via "Zero Tolerance" Detention Policy" [daring]. dalam https://www.justsecurity. org/58783/global-responses-president-trumps-family-separation-zero-tolerancedetention-policy/ [diakses pada 26 Desember 2018].

BBC, 2018. "US Child Migrants: Over 700 Not Reunited with Families by Deadline", $B B C$ News, 27 Juli, [daring]. dalam https://www.bbc.com/news/world-uscanada-44975126 [diakses pada 26 Desember 2018].

Bruce, N. C., 2018. "U.N. Rights Chief Tells U.S. to Stop Taking Migrant Children From Parents", The New York Times, 18 Juni, [daring]. dalam https://www.nytimes. com/2018/o6/18/world/europe/trump-migrant-children-un.html [diakses pada 5 Januari 2019]

Bump, P., 2018. "Here Are the Administration Officials Who Have Said that family separation is meant as a deterrent”, The Washington Post, 19 Juni, [daring]. dalam https://www.washingtonpost.com/news/politics/wp/2018/o6/19/here-arethe-administration-officials-who-have-said-that-family-separation-is-meant-as-adeterrent/ [diakses pada 19 Juni 2019].

Burnett, J., 2019. "Sexual Assault Of Detained Migrant Children Reported In The Thousands Since 2015", National Public Radio, 26 Februari, [daring]. dalam https://www.npr.org/2019/02/26/698397631/sexual-assault-of-detained-migrantchildren-reported-in-the-thousands-since-2015 [diakses pada 26 Juli 2019].

CNN Investigates, 2018. "Handcuffs, assaults, and drugs called 'vitamins': Children allege grave abuse at migrant detention facilities" [daring]. dalam https://edition. cnn.com/2018/o6/21/us/undocumented-migrant-children-detention-facilities-abuseinvs/index.html [diakses pada 4 Mei 2019].

Davis, J., 2018. "US 'zero-tolerance' immigration policy still violating fundamental human rights laws", The Conversation, 27 Juni, [daring]. dalam https:// theconversation.com/us-zero-tolerance-immigration-policy-still-violatingfundamental-human-rights-laws-98615 [diakses pada 15 Mei 2020].

Dawsey, M. V., 2018. "In the closing days of the election, Trump turns to his favorite weapon: Immigration", The Washington Post, 27 Oktober, [daring]. dalam https://www.washingtonpost.com/politics/in-the-closing-days-of-the-election-trumpturns-to-his-favorite-weapon-immigration/2018/10/25/7c42fa44-d79f-11e8-83a2d1c3da28d6b6_story.html?utm_term=.9af1aba3f482 [diakses pada 4 Mei 2019].

Frazee, G., 2018. "4 Myths About How Immigrants Affect the U.S. Economy”, PBS News Hour, 2 November, [daring]. dalam https://www.pbs.org/newshour/economy/ making-sense/4-myths-about-how-immigrants-affect-the-u-s-economy [diakses pada 26 Mei 2020].

Gumbel, A., 2018. “They were laughing at us: Immigration tell of cruelty, illness and filth in US detention", The Guardian, 12 September, [daring]. dalam https://www. theguardian.com/us-news/2018/sep/12/us-immigration-detention-facilities [diakses pada 26 Mei 2020].

Haag, M., 2019. "Thousands of Immigrant Children Said They Were Sexually Abused in U.S. Detention Centers", The New York Times, 27 Februari, [daring]. dalam https://www.nytimes.com/2019/02/27/us/immigrant-children-sexual-abuse.html 
[diakses pada 26 Mei 2020].

Hildreth, M., 2019. Immigration 101: What is Zero Tolerance Family Separation?” [daring]. dalam https://americasvoice.org/blog/separation-of-children/ [diakses pada 11 Mei 2019].

Human Rights Watch, 2018. “Q\&A: Trump Administration's 'Zero-Tolerance' Immigration Policy" [daring]. dalam https://www.hrw.org/news/2018/o8/16/ qa-trump-administrations-zero-tolerance-immigration-policy [diakses pada 29 Desember 2018].

International Rescue Committee, 2018. "What happens to children who are separated from their parents?” [daring]. dalam https://www.rescue.org/article/what-happenschildren-who-are-separated-their-parents [diakses pada 27 Mei 2020].

Jacobs, J., 2019. "U.S. Says It Could Take 2 Years to Identify Up to Thousands of Separated Immigrant Families", The New York Times, 6 April, [daring]. dalam https://www.nytimes.com/2019/04/o6/us/family-separation-trump-administration. html [diakses pada 26 Mei 2020].

Jordan, M., 2018. "How and Why 'Zero Tolerance' Is Splitting Up Immigrant Families.", The New York Times, 12 Mei, [daring]. dalam https://www.nytimes. com/2018/05/12/us/immigrants-family-separation.html [diakses pada 28 Desember 2018].

Jordan, M., 2019. "Family Separation May Have Hit Thousands More Migrant Children Than Reported", The New York Times, 17 Januari, [daring]. dalam https://www. nytimes.com/2019/01/17/us/family-separation-trump-administration-migrants.html [diakses pada 27 Mei 2020].

Lind, D., 2019. “Immigrants Are Coming Over the Border to Kill You' is the Only Speech Trump Knows How to Give", Vox, 9 Januari, [daring]. dalam https:// www.vox.com/2019/1/8/18174782/trump-speech-immigration-border [diakses pada 27 Mei 2020].

Lopez, G., 2018. “The Research on Race that Helps Explain Trump's Use of Family Separation at The Border", Vox, 19 Juni, [daring]. dalam https://www.vox.com/ identities/2018/6/19/17478970/trump-family-separation-immigration-policy-racism [diakses pada 15 Mei 2020].

Lussenhop, J., 2018. "The Health Impact of Separating Migrant Children from Parents", BBC, 19 Juni, [daring]. dalam https://www.bbc.com/news/world-uscanada-4452890o [diakses pada 27 Mei 2020].

Narea, N., 2019. "The Trump Administration Just Admitted that It Separated An Additional 1,500 Immigrant Families”, Vox, 25 Oktober, [daring]. dalam https:// www.vox.com/policy-and-politics/2019/10/25/20931992/trump-administration-aclulawsuit-separate-families-immigrant-policy-1500 [diakses pada 15 Mei 2020].

Nathan, D., 2018. "Children Separated Under Trump's "Zero Tolerance' Policy Say Their Trauma Continues", The Intercept, 26 Agustus, [daring]. dalam https:// theintercept.com/2018/08/26/children-separated-under-trumps-zero-tolerancepolicy-say-their-trauma-continues/ [diakses pada 26 Mei 2020].

Radford, J., 2019. "Key Findings about U.S. immigrants", Pew Research Center, 17 Juni, [daring]. dalam https://www.pewresearch.org/fact-tank/2019/06/17/keyfindings-about-u-s-immigrants/ [diakses pada 26 Mei 2020].

Redlener, I., 2019. "A 16-year-old boy died in CBP custody. Blame immigration policy”, The Washington Post, 23 Mei, [daring]. dalam https://www.washingtonpost. com/opinions/dont-blame-border-patrol-for-child-deaths-at-the-border-blame- 
immigration-policy/2019/05/23/f9477ao6-7d76-11e9-8bb7-ofc796cf2eco_story. html?utm_term=.7d479fa441bf [diakses pada 26 Mei 2020].

Rizzo, S., 2018. “The Trump administration's questionable data on family separations", The Washington Post, 12 Oktober, [daring]. dalam https://www.washingtonpost. com/politics/2018/10/12/trump-administrations-questionable-data-familyseparations/?utm_term $=.2 f 0664 f$ f $958 f$ [diakses pada 26 Mei 2020].

Romero, S., et al., 2019. "Hungry, Scared and Sick: Inside the Migrant Detention Center in Clint, Tex", The New York Times, 6 Juli, [daring]. dalam https://www. nytimes.com/interactive/2019/07/06/us/migrants-border-patrol-clint.html [diakses pada 15 Mei 2020].

Tatum, S., 2019. "HHS docs show thousands of alleged incidents of sexual abuse against unaccompanied minors in custody", CNN Politics, 26 Februari, [daring]. dalam https://edition-m.cnn.com/2019/02/26/politics/hhs-documents-minorssexual-abuse/index.html?r=https\%3A\%2F\%2Fwww.google.com\%2F [diakses pada 26 Mei 2020].

Thompson, G., 2018. "Families still being separated at border - months after Trump's 'zero tolerance' policy reversed", USA Today, 27 November, [daring]. dalam https://www.usatoday.com/story/news/politics/elections/2018/11/27/donald-trumpzero-tolerance-policy-border-migrants-families-separated-immigration/2132426002/ [diakses pada 29 Desember 2018].

Watson, R., 2018. "Migrant Children Shelters: Mats, Meals, but No Human Touch", Psychology Today, 23 Juni, [daring]. dalam https://www.psychologytoday.com/us/ blog/love-and-gratitude/201806/migrant-children-shelters-mats-meals-no-humantouch [diakses pada 26 Mei 2020].

Whitesides, J., 2020. "Factbox: Trump and Biden Take Sharply Different Paths on Immigration", US News, 22 April, [daring]. dalam https://www.usnews.com/ news/us/articles/2020-04-22/factbox-trump-and-biden-take-sharply-different-pathson-immigration [diakses pada 26 Mei 2020].

Wiley, H., 2018. "Hundreds of migrant kids haven't been reunited with their parents. What's taking so long?", The Texas Tribune, 4 Oktober, [daring]. dalam https://www.texastribune.org/2018/10/o4/zero-tolerance-policy-reunite-separatedimmigrant-families/ [diakses pada 26 Mei 2020].

\section{Lain-lain}

Brane, M., 2019, “The Department of Homeland Security's Family Separation Policy: Perspectives from the Border" [online]. dalam https://homeland.house.gov/imo/ media/doc/Testimony-Brane.pdf [diakses pada 1 Juli 2019].

Collins English Dictionary, t.t. "Zero Tolerance" [online]. dalam https://www. collinsdictionary.com/dictionary/english/zero-tolerance [diakses pada 29 Desember 2018].

Congressional Research Service, 2019. "Immigration: U.S. Asylum Policy" [daring]. dalam https://crsreports.congress.gov/product/pdf/R/R45539 [diakses pada 4 Mei 2019].

Correa-Cabrera, G. dan T. Payan, 2018. "Political Turpitude: The Negative Impact of Zero-Tolerance Immigration Policies on Irregular Labor Markets", Issue Brief, No.07.09.18.

Department of Homeland Security, 2018. "ICE's Inspections and Monitoring of Detention Facilities Do Not Lead to Sustained Compliance or Systemic 
Improvements" [daring]. dalam https://www.oig.dhs.gov/sites/default/files/ assets/2018-06/OIG-18-67-Jun18.pdf [diakses 26 Mei 2020].

Department of Justice, 2018. "Attorney General Announces Zero-Tolerance Policy for Criminal Illegal Entry" [daring]. dalam https://www.justice.gov/opa/pr/attorneygeneral-announces-zero-tolerance-policy-criminal-illegal-entry [diakses pada $15 \mathrm{Mei}$ 2020].

Hart, S., t.t. "How Has Inequality Been a Cause of Violence in Postdictatorship Brazil?" [daring].dalamhttps://business.leeds.ac.uk/download/downloads/id/138/how_has_ inequality_been_a_cause_of_violence_in_post-dictatorship_brazil.pdf [diakses pada 27 Mei 2020].

History.com Editors, 2009. “U.S. Immigration Before 1965” [daring]. dalam https:// www.history.com/topics/immigration/u-s-immigration-before-1965 [diakses pada 28 Desember 2018].

Kandel, W.A., 2018. The Trump Administration's “Zero Tolerance” Immigration Enforcement Policy. Report No. R45266. Washington, DC: Governmental Printing Office.

Mayda, A.M., dan G. Peri, 2018. "The political impact of immigration: Evidence from the United States" National Bureau of Economic Research, No. w24510.

Office of Refugee Resettlement, 2015. "Children Entering the United States Unaccompanied: Section 1" [daring]. dalam https://www.acf.hhs.gov/orr/resource/ children-entering-the-united-states-unaccompanied-section-1 [diakses pada $27 \mathrm{Mei}$ 2020].

Phillips, K., 2018. "Reports have spread that shelter workers can't comfort migrant children. Rules aren't that simple", The Washington Post, 20 Juni, [daring]. dalam https://www.washingtonpost.com/news/post-nation/wp/2018/o6/20/reportshave-spread-that-shelter-staff-cant-comfort-migrant-children-rules-arent-thatsimple/?utm_term=.236doc480096 [diakses pada 26 Mei 2020].

Physicians for Human Rights, 2018. "U.S. Immigration Policy Contributes to Another Child Death" [daring]. dalam https://phr.org/resources/u-s-immigration-policycontributes-to-another-child-death/ [diakses pada 26 Mei 2020].

Pierce, S. dan A. Selee, 2017. "Immigration under Trump: A review of policy shifts in the year since the election", Migration Policy Institute, Desember.

The White House, 2019. "President Trump's Bold Immigration Plan for the 21st Century" [daring]. dalam https://www.whitehouse.gov/articles/president-trumpsbold-immigration-plan-21st-century/ [diakses pada 27 Mei 2020].

U.S. Customs and Border Protection, 2018. "Zero Tolerance Immigration ProsecutionsFamily Fact Sheet" [daring]. dalam https://www.cbp.gov/newsroom/zero-toleranceimmigration-prosecutions-family-fact-sheet [diakses pada 26 Desember 2018].

U.S. House of Representative, 2019. Child Separation by Trump Administration" [daring]. dalam https://oversight.house.gov/sites/democrats.oversight.house.gov/ files/2019-07-2019.\%20Immigrant\%20Child\%20Separations-\%20Staff\%20Report.pdf [diakses pada 27 Mei 2020]. 
The United States' Zero Tolerance Immigration Policy: An Analysis of Structural Violence 